\title{
The role of the entorhinal cortex in epileptiform activities of the hippocampus
}

\author{
Hui Ren', Ye-Jun Shi' ${ }^{2}$ Qin-Chi Lu², Pei-Ji Liang ${ }^{1}$ and Pu-Ming Zhang ${ }^{1 *}$
}

\author{
* Correspondence: \\ pmzhang@sjtu.edu.cn \\ ${ }^{1}$ School of Biomedical Engineering, \\ Shanghai Jiao Tong University, \\ Shanghai 200240, China \\ Full list of author information is \\ available at the end of the article
}

\begin{abstract}
Background: Temporal lobe epilepsy (TLE) is the commonest type of epilepsy in adults, and the hippocampus is indicated to have a close relationship with TLE. Recent researches also indicate that the entorhinal cortex (EC) is involved in epilepsy. To explore the essential role that the EC may play in epilepsy, a computational model of the hippocampal CA3 region was built, which consisted of pyramidal cells and two types of interneurons. By changing the input signals from the EC, the effects of EC on epileptiform activities of the hippocampus were investigated. Additionally, recent studies have found that the antiepileptic drug valproate (VPA) can block ictal discharges but cannot block interictal discharges in vitro, and the mechanism under this phenomenon is still confusing. In our model, the effects of VPA on epileptiform activities were simulated and some mechanisms were explored.

Results: Interictal discharges were induced in the model without the input signals from the $E C$, whereas the model with the EC input produced ictal discharges when the EC input contained ictal discharges. The GABA-ergic connection strength was enhanced and the NMDA-ergic connection strength was reduced to simulate the effects of VPA, and the simulation results showed that the disappearance of ictal discharges in the model mainly due to the disappearance of ictal discharges in the input signals from the EC.

Conclusions: Simulation results showed that ictal discharges in the EC were necessary for the hippocampus to generate ictal discharges, and VPA might block the ictal discharges in the EC, which led to the disappearance of ictal discharges in the hippocampus.
\end{abstract}

Keywords: Computational model, Hippocampal CA3 region, Entorhinal cortex, Valproate, Temporal lobe epilepsy

\section{Introduction}

Temporal lobe epilepsy (TLE) is the commonest type of epilepsy in adults, and about $75 \%$ of patients with mesial TLE are considered to have drug-resistant epilepsy [1]. It has been commonly accepted that the hippocampus has a close relationship with the generation of TLE. In specimens from surgical resections and post-mortem studies of patients with TLE, neuronal loss, atrophy, and gliosis have been revealed in the hippocampus [2]. It has been reported that epileptiform activities depend crucially on intrinsic neuronal properties, and the organisation of the synaptic networks [3]. The hippocampus has massive recurrent excitatory connections, intrinsically burst-generating cells, as well as closely spaced cell bodies and dendrites, and these all make it easy to generate epileptiform activities $[4,5]$.

(c) 2014 Ren et al.; licensee BioMed Central Ltd. This is an Open Access article distributed under the terms of the Creative Commons Attribution License (http://creativecommons.org/licenses/by/2.0), which permits unrestricted use, distribution, and reproduction in any medium, provided the original work is properly credited. The Creative Commons Public Domain Dedication waiver (http://creativecommons.org/publicdomain/zero/1.0/) applies to the data made available in this article, unless otherwise stated. 
In spite of the essential role that the hippocampus plays in the generation of epileptiform activities, observations in animal models also have indicated that the epileptogenic zone is broad, and some other limbic regions may be involved in the generation of TLE as well [2]. Now, many scientists have shown much interest in the role the entorhinal cortex (EC) plays in epilepsy [6]. Magnetic resonance imaging studies showed that the EC was damaged in patients with TLE [7], and observations in both rats and patients with TLE displayed preferential neuronal loss in the EC $[8,9]$. There exist extensive reciprocal connections between the EC, hippocampus, and other brain areas, which make the EC a potential candidate for generating and propagating TLE seizures [10].

Epileptiform activities appear as interictal discharges and ictal discharges. Interictal discharges are the simplest identifiable epileptiform activities, which last tens or hundreds of milliseconds [4], and ictal discharges (also termed seizures) represent the critical events and the primary clinical burden of an active epileptic condition, which usually last more than 10 seconds $[4,11]$. It has been suggested that the EC may contribute to the initiation of ictal discharges $[6,12,13]$. It was reported that cutting the perforant pathway blocked the ictal discharges in the hippocampus, but not in the EC, where ictal discharges continued to occur with similar features compared to those seen in the combined EC-hippocampal slices where the perforant pathway was preserved $[6,14]$. Our laboratory has done researches about epileptiform activities induced by $\mathrm{Mg}^{2+}$-free artificial cerebrospinal fluid (ACSF), which unblocks the N-methyl-D-aspartate (NMDA) receptors, in hippocampal slices and combined EC-hippocampal slices as well [15-19]. We found that ictal discharges were only induced in the combined EC-hippocampal slices, which indicated that the EC was very essential for the hippocampus to initiate ictal discharges $[18,19]$. Although the EC has been shown to have a close relationship with the generation of epileptiform activities, the exact role it plays in epilepsy is still unclear.

Many experimental studies in hippocampal slices indicated that the CA3 field was the place that could generate interictal activities [6,20]. Pyramidal cells in the CA3 receive signals from the dentate gyrus (DG) via mossy fibers, and from the EC via the perforant pathway, and they project to the CA1 [21]. Divergent connections of the CA3 pyramidal cells with local cells and cells of the other fields allow for the expansion of synchronous population discharges [20]. Many models of the CA3 field had been built to investigate the mechanisms of different epileptiform activities, such as carbachol-driven rhythmic population oscillations [22], picrotoxin-induced synchronized after-discharges [23], or low- $\mathrm{Mg}^{2+}$ induced neuronal bursts and after-discharges [24]. But they only simulated interictal discharges and didn't consider the impacts that the EC may make on epileptiform activities of the hippocampus.

Valproate (VPA) is one of the major antiepileptic drugs (AEDs) used today, and its ability to control epileptiform activities mainly depends on enhancing the GABA-ergic inhibitory functions and reducing the NMDA-ergic excitatory functions of the nervous system [25]. Researchers have found that VPA could block ictal discharges but couldn't completely block interictal discharges in vitro [26-28]. In our experiments, we also found that the application of $3 \mathrm{mM}$ VPA suppressed the frequency of interictal discharges and completely blocked the ictal discharges in the combined EC-hippocampal slices [19]. However, the mechanism of this phenomenon is still confusing.

In this work, we built a model of the hippocampal CA3 region to simulate interictal and ictal discharges based on NEURON [29]. The model contained 4 neurons including 
2 pyramidal cells, one basket cell and one oriens-lacunosum molecular (OLM) cell. The model contained 2 inputs which were from the DG and EC respectively. Simulation results indicated that interictal discharges were induced in the model without the EC input, whereas the model with the EC input produced ictal discharges when the EC input contained ictal discharges. From the results, we supposed that ictal discharges from the EC were necessary for the hippocampus to generate ictal discharges. In our model, the GABA-ergic inhibitory connections were enhanced and the NMDA-ergic excitatory connections were reduced to simulate the effects of VPA. Simulation results showed that the disappearance of ictal discharges in the model mainly due to the disappearance of ictal discharges of the input signals from the EC. Thus, we supposed that VPA might block the ictal discharges in the EC of combined EC-hippocampal slices, which led to the disappearance of ictal discharges in the hippocampus.

\section{Results}

Simulation reproduces $\mathrm{Mg}^{2+}$-free-ACSF induced interictal discharges

In our experiments, the application of $\mathrm{Mg}^{2+}$-free-ACSF consistently induced interictal discharges in adult rat hippocampal slices [15-17] and adult mouse hippocampal slices $[18,19]$. Figure $1 \mathrm{~A}$ shows an example of $\mathrm{Mg}^{2+}$-free-ACSF induced interictal discharges in one mouse hippocampal slice. These signals were local field potentials (LFPs) recorded by one electrode of the micro-electrode array (MEA) located in the CA3 region. The onset of interictal discharges in different slices appeared with different time delays after $\mathrm{Mg}^{2+}$-free-ACSF perfusion began, ranging between 10 and $20 \mathrm{~min}(15.8 \pm 2.6 \mathrm{~min}, \mathrm{n}=4$ slices) [18]. Signals measured in the model were the membrane potentials of pyramidal cells, which seemed similar to the intracellular recordings and different from LFPs recorded in experiments as shown in Figure 1A. LFPs were the electric potentials recorded in the extracellular space and it had been shown that LFPs were synchronized with intracellular recordings in the same region during epileptiform activities [27,30].

As the hippocampal slices didn't contain EC, we only considered the input from the DG, which followed a Poisson process $(\lambda=1)$ [31] in this model (Figure 1B). The somatic membrane potentials of one pyramidal cell under different $\mathrm{Mg}^{2+}$ concentrations were plotted in Figure 1C. When the $\mathrm{Mg}^{2+}$ concentration was $1.0 \mathrm{mM}$, which was the normal $\mathrm{Mg}^{2+}$ concentration in the extracellular solution [32], interictal discharges were absent. However, when the $\mathrm{Mg}^{2+}$ concentration was changed to $0 \mathrm{mM}$, interictal discharges occurred. Every single burst of interictal discharges consisted of a train of several spikes riding on a large depolarizing wave, which was similar to the paroxysmal depolarizing shift recorded in experiments $[4,33]$. What's more, the interictal discharges in the simulation occurred when the input signals followed a Poisson process, which supported the viewpoint, indicated in many experimental studies, that the CA3 field could generate interictal activities $[6,16,18-20]$.

\section{Ictal and interictal discharges induced by the EC input}

In our experiments, two types of epileptiform discharges were recorded in the mouse combined EC-hippocampal slices during the application of $\mathrm{Mg}^{2+}$-free-ACSF (Figure 2A). Interictal discharges occurred regularly in the CA3 region, and they generally appeared before an ictal discharge with a frequency of $0.22 \pm 0.06 \mathrm{~Hz}$, and the frequency of ictal 


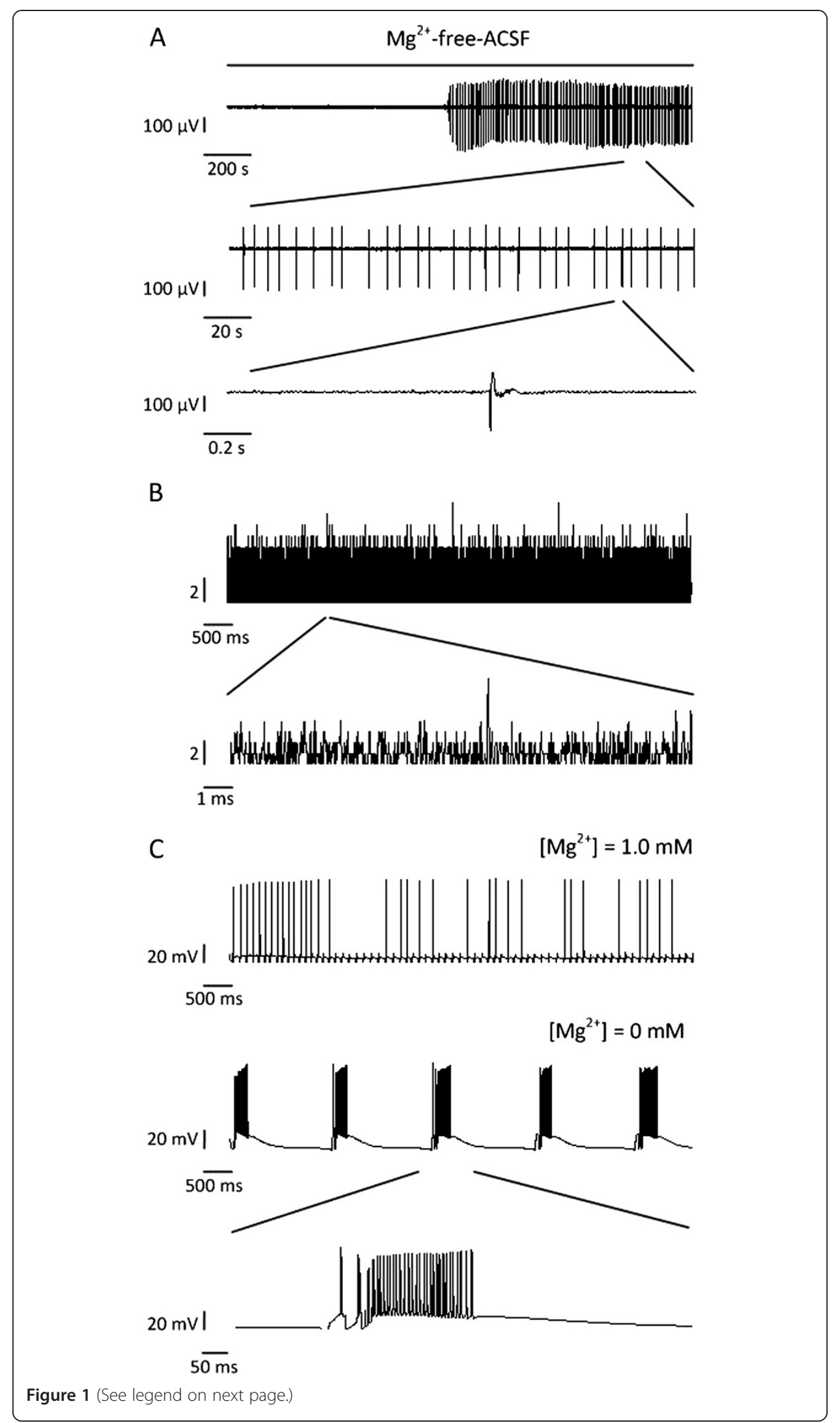


(See figure on previous page.)

Figure 1 Interictal discharges in experiments and in the model, and input signals from DG. (A) LFPS in $C A 3$ region recorded by MEA in a hippocampal slice. Interictal discharges occurred with more than 10 minutes' delays after $\mathrm{Mg}^{2+}$-free-ACSF perfusion. (B) Simulated input signals from the DG which followed a Poisson process $(\lambda=1)$. (C) Somatic membrane potentials of one pyramidal cell under different $\mathrm{Mg}^{2+}$ concentrations in the model without the input from the EC. Interictal discharges occurred when $\left[\mathrm{Mg}^{2+}\right]$ was $0 \mathrm{mM}$. $\left[\mathrm{Mg}^{2+}\right]$ : extracellular $\mathrm{Mg}^{2+}$ concentration.

discharges was about $0.004 \pm 0.001 \mathrm{~Hz}(\mathrm{n}=4$ slices) [18]. The epileptiform activities measured in the DG and EC were synchronized with those measured in the CA3 region $[18,19,34]$. Also, according to experimental studies, the EC was indicated to be the first site to produce ictal discharges in combined EC-hippocampal slices $[6,18,19]$. In this model, interictal and ictal discharges were added into the network to simulate inputs from the EC and DG (Figure 2B). As a result, the pyramidal cells in the model produced interictal and ictal discharges (Figure 2C). The interictal discharges appeared before an ictal discharge with a frequency of $0.2 \mathrm{~Hz}$ and the ictal discharges appeared with a frequency of $0.005 \mathrm{~Hz}$. These patterns were synchronized with the input signals, which supported the viewpoint that synchronized firing occurred during $\mathrm{Mg}^{2+}$-free-ACSF induced epileptiform activities [24].

In the simulation, ictal discharges occurred when the input signals from the EC and DG contained ictal activities, and there were no reports or experimental results showing that the DG was the first place to generate ictal discharges. We supposed that ictal discharges in the hippocampus were induced by the EC. To confirm this supposition, we set the input from the DG as signals followed a Poisson process $(\lambda=1)$ as shown in Figure 1B, and didn't change the input from the EC (Figure 2B). The simulation result showed that ictal discharges still occurred (Figure 2D). In this way, we deduced that the EC induced the hippocampus to generate ictal discharges in combined EC-hippocampal slices.

\section{Effects of VPA on the epileptiform activities}

In our experiments, the application of $3 \mathrm{mM}$ VPA suppressed the frequency of interictal discharges induced by $\mathrm{Mg}^{2+}$-free-ACSF, but could not completely block them in the mouse hippocampal slices [19], and one example was shown in Figure 3A. In the model without the input from the EC, the GABA-ergic inhibitory connection strength was enhanced and the NMDA-ergic excitatory connection strength was reduced to simulate the effects of VPA on interictal activities. Figure 3B shows one example of the membrane potentials of one pyramidal cell when the GABA-ergic connection strength is tripled and the NMDA-ergic connection strength is reduced by $20 \%$ in the model. We found that the frequency of interictal discharges decreased about $22.2 \%$.

According to our experimental studies in the mouse combined EC-hippocampal slices, the application of $3 \mathrm{mM}$ VPA completely blocked ictal discharges, and suppressed but didn't completely block interictal discharges (Figure 4A). The frequency of interictal discharges changed from $0.22 \pm 0.06 \mathrm{~Hz}$ to $0.15 \pm 0.03 \mathrm{~Hz}$ ( $\mathrm{n}=4$ slices) [19]. Suggested by the experimental data, the EC and DG produced interictal discharges with lower frequencies after the application of VPA in combined EC-hippocampal slices [27]. Thus, in the model with the input from the EC, interictal discharges with a frequency of $0.15 \mathrm{~Hz}$ were added 


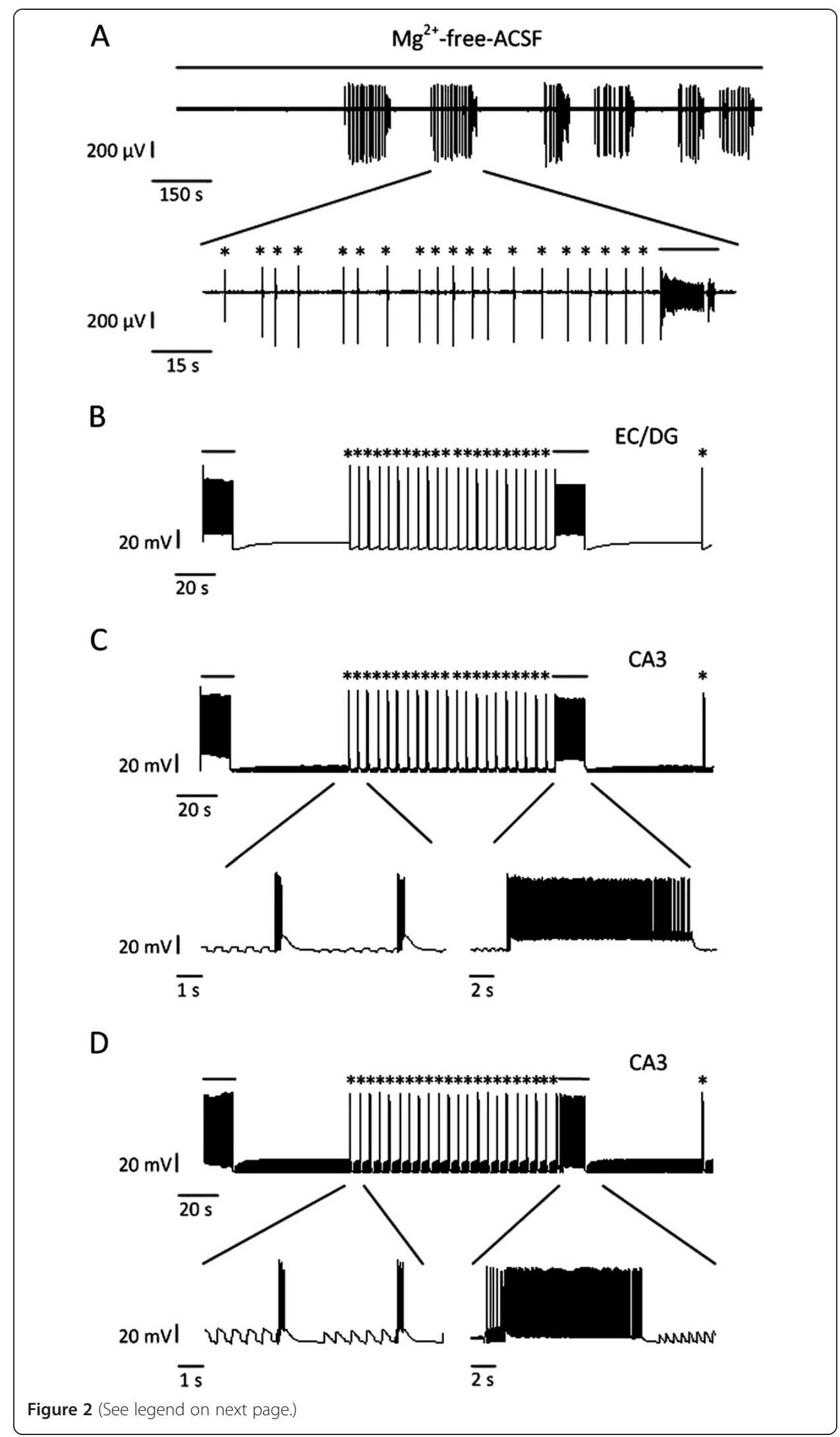


(See figure on previous page.)

Figure $\mathbf{2}$ Interictal (asterisks) and ictal (continuous lines) discharges in experiments and the model, and input signals. (A) LFPS in the CA3 region recorded by MEA in a combined EC-hippocampal slice. Interictal discharges occurred regularly before an ictal discharge. (B) Simulated input signals from the DG or EC, which were alternate interictal and ictal discharges. (C) Somatic membrane potentials of one pyramidal cell in the model with the input from the EC. When input signals from the DG and EC were alternate interictal and ictal discharges as shown in (B), pyramidal cells in the model produced interictal and ictal discharges. (D) Somatic membrane potentials of one pyramidal cell in the model with the input from the EC. When the input signals from the DG followed a Poisson process as shown in Figure 1B and the input signals from the EC were alternate interictal and ictal discharges as shown in (B), pyramidal cells in the model produced interictal and ictal discharges.

A $\mathrm{Mg}^{2+}$-free-ACSF

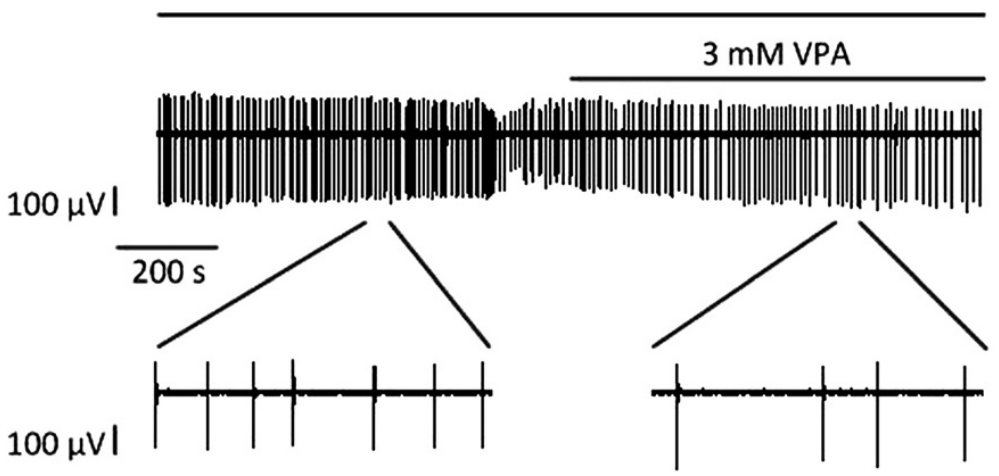

$10 \mathrm{~s}$

B

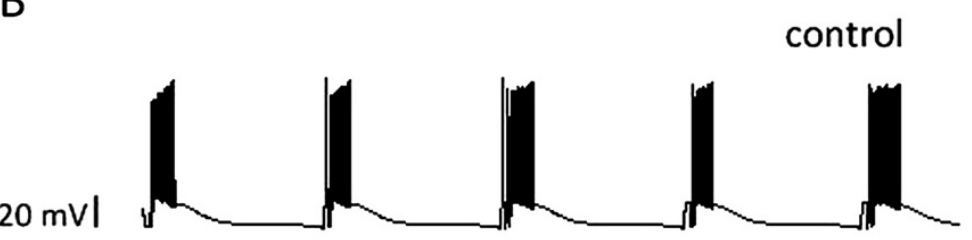

$5 \overline{00 \mathrm{~ms}}$

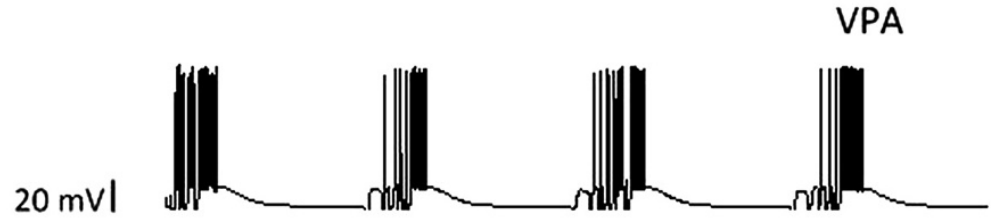

\section{$50 \overline{\mathrm{ms}}$}

Figure 3 Effects of VPA on interictal activities in experiments and simulations. (A) Interictal discharges before and during $3 \mathrm{mM}$ VPA application in one hippocampal slice, which represents the recording of one electrode in the CA3 region. (B) The somatic membrane potentials of one pyramidal cell in the model without the EC input. The input signals from the DG followed a Poisson process as shown in Figure 1B. When the GABA-ergic connection strength was enhanced and the NMDA-ergic connection strength was reduced, the frequency of interictal discharges decreased. 


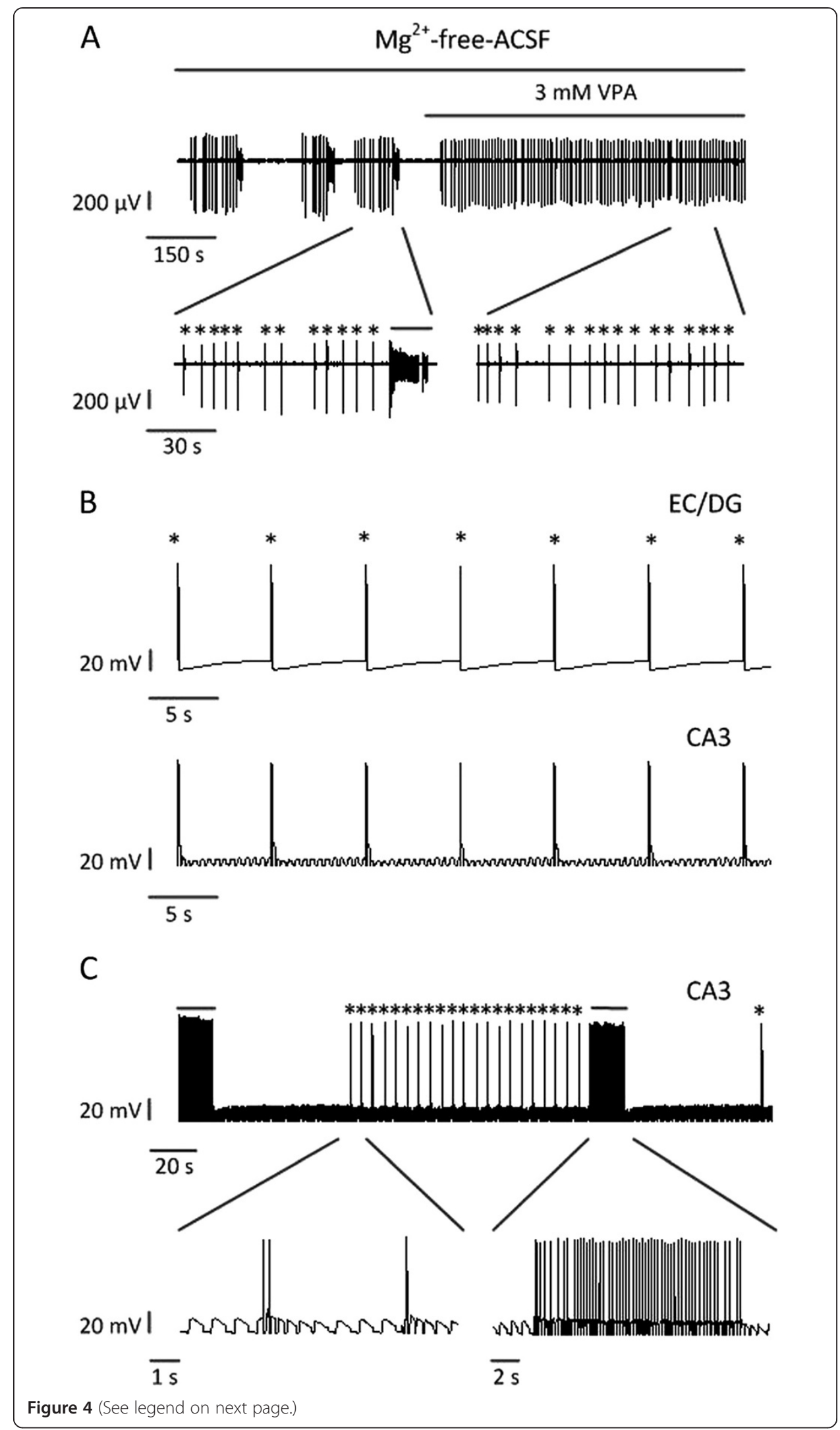


(See figure on previous page.)

Figure 4 Effects of VPA on interictal (asterisks) and ictal (continuous lines) activities in experiments and simulations. (A) Epileptiform discharges before and during $3 \mathrm{mM}$ VPA application in a combined EC-hippocampal slice, which represents the recordings of one electrode in the CA3 region. (B) The somatic membrane potentials of a pyramidal cell in the model with the input from the EC. When the GABA-ergic connection strength was enhanced and the NMDA-ergic connection strength was reduced, and the input signals from the EC and DG were interictal discharges with a lower frequency compared to interictal discharges added previously as shown in Figure 2B, ictal discharges disappeared and interictal discharges still existed. (C) The somatic membrane potentials of a pyramidal cell in the model with the input from the EC. When the GABA-ergic connection strength was enhanced and the NMDA-ergic connection strength was reduced, and the input signals from the DG followed a Poisson process as shown in Figure 1B, and the input signals from the EC were alternate interictal and ictal discharges as shown in Figure 2B, ictal and interictal discharges still existed.

into the network to simulate input signals from the EC and DG (Figure 4B). The pyramidal cells in the model produced interictal discharges synchronized with the input signals (data not shown). When the GABA-ergic connection strength was enhanced more than 10 times and the NMDA-ergic connection strength was reduced by more than $20 \%$, the interictal discharges still existed and were synchronized with the input signals (Figure 4B). Thus, VPA blocked the ictal discharges but could not block the interictal discharges.

The disappearance of ictal discharges in the model seemed due to the disappearance of ictal discharges in the input signals. In this way, we supposed that VPA might block the ictal discharges in the EC of the combined EC-hippocampal slices, which led to the disappearance of ictal discharges in the hippocampus. To confirm this opinion further, ictal and interictal discharges were added into the model to simulate the input signals from the EC, and the signals followed a Poisson process $(\lambda=1)$ were added into the model to simulate the input signals from the DG. The model generated interictal and ictal discharges as shown in Figure 2D. When the GABA-ergic connection strength was enhanced more than 50 times and the NMDA-ergic connection strength was reduced by more than 20\%, the ictal and interictal discharges still existed (Figure 4C). The results suggested that VPA could not block ictal discharges in the hippocampus when the EC contained ictal discharges. Thus, we deduced that during the application of VPA in combined EC-hippocampal slices, the disappearance of ictal discharges in the hippocampus might result from the disappearance of ictal discharges in the EC.

\section{Discussion}

In this work, we established a model of the hippocampal CA3 region to characterize the effects of the EC on the hippocampal epileptiform activities. In the model without the input from the $\mathrm{EC}$, interictal discharges were induced by changing the $\mathrm{Mg}^{2+}$ concentration to $0 \mathrm{mM}$, which supported the viewpoint that CA3 field could generate interictal activities [6]. In the model with the input from the EC, which contained interictal and ictal discharges, pyramidal cells of the model generated interictal and ictal discharges. Additionally, when the input signals from the DG followed a Poisson process and the input signals from the EC contained ictal discharges, pyramidal cells of the model generated ictal discharges. From the simulation results, we deduced that the EC was the first place to generate ictal discharges in combined EC-hippocampal slices, which was suggested in many previous experimental studies [6,12-14]. Finally, the GABA-ergic inhibitory connection strength was enhanced and the NMDA-ergic excitatory connection strength was reduced to simulate 
the effects of VPA. As the ictal discharges of the model disappeared when the input signals from the EC didn't contain ictal discharges, we supposed that the disappearance of ictal discharges in the hippocampus of combined EC-hippocampal slices might due to the disappearance of ictal discharges in the EC. In this way, we deduced that VPA might block the ictal discharges in the EC of combined EC-hippocampal slices, which led to the disappearance of ictal discharges in the hippocampus.

Many people have built models of the CA3 region to investigate possible mechanisms of epileptiform activities [22-24,35]. Those models were very large and contained at least hundreds of neurons. Some other people built models of the CA3 region to do researches of the other problems such as schizophrenia [31,36,37]. Those models contained more than 10 neurons. Compared to the models built previously, the model built here was much smaller and only contained 4 neurons. Our model contained the pyramidal cell, the basket cell and the OLM cell, which were the commonest neurons in the CA3 model [31,36,37]. Connections between these neurons were based on anatomical study results $[21,38]$. The model also contained the commonest receptors, which were AMPA, NMDA and $\mathrm{GABA}_{\mathrm{A}}$ receptors [31,35]. Although our model was small, it could generate epileptiform activities and simulate the effects of VPA. But, this small model has many limits. It has been reported that the epileptiform activities may firstly occur in a small number of pyramidal neurons, and then spread to other pyramidal neurons [23]. With our small model, we cannot simulate the spread of epileptiform activities. Additionally, it has been shown that during different periods of epileptiform activities, the number of pyramidal cells that fire synchronously is different [24]. Since there are only two pyramidal cells in our model, it cannot simulate that phenomenon.

The pyramidal cells built in this model were burst generating cells, as it had been reported that most pyramidal cells in the CA3 field could generate bursts and the generation of epileptiform activities were related to the burst generating cells [4,5,39]. However, the CA3 field also contains nonbursting pyramidal cells, which show action potentials with a property of spike frequency adaption after the application of somatic current injections $[21,39]$. The discharges of bursting pyramidal cells always precede the population discharges, and bursting pyramidal cells may be the pacemakers of epileptiform activities, whereas nonbursting pyramidal cells only discharge simultaneously with the population discharges during epileptiform activities [40]. So, in our model, we didn't consider the nonbursting pyramidal cells. But, if we want to research the details of the firing pattern of epileptiform discharges, we may need to consider the nonbursting pyramidal cells.

In normal physiological conditions, the structure of the pyramidal cell is very complex [39], and many people have built different reconstructed CA3 pyramidal cell models. Some models contained more than 200 compartments [39,41], and some contained more than 10 compartments [22-24], or only several compartments [31,36]. The pyramidal cell built in our model consisted of 4 compartments: one somatic and 3 dendritic compartments (Figure 5). Although the structure of this cell model was different from many other models, its responses to the somatic current injections were similar to the firing patterns of pyramidal cells measured in experiments [39]. However, the distribution of ion channels in this cell model could not be the same as that in the cell models whose structures were similar with that of a real pyramidal cell, which made this model's output have some differences with the real pyramidal cells' firing activities. If we investigate the effects of the firing pattern or the distribution of some 


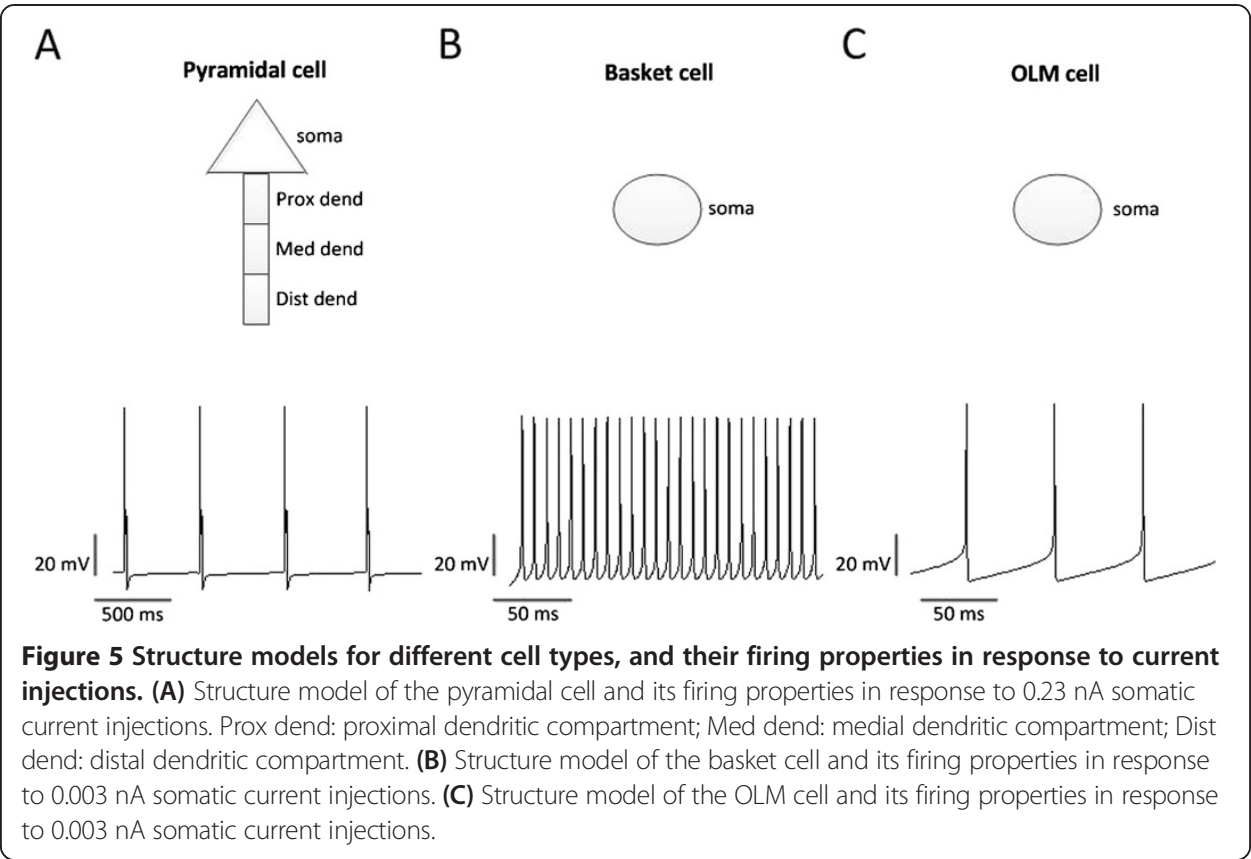

ion channels of pyramidal cells on the epileptiform activities, we may need to build more detailed pyramidal cells in the future work.

There are many types of interneurons in the CA3 field. In this model, we only considered the basket cell and the OLM cell, which were 2 common types in the CA3 field $[21,38]$. However, there exist some other types of perisomatic-targeting interneurons (such as the axo-axonic cells) and dendritic-targeting interneurons (such as the bistratified cells) in the CA3 field [21]. The acting sites towards pyramidal cells and the firing patterns of these cells are similar to the basket cells or the OLM cells, but there still exist some differences. The axo-axonic cells project to the proximal dendrites of pyramidal cells and the bistratified cells project to the medial dendrites of pyramidal cells [21,38]. So considering these interneurons may make the CA3 model more reliable. However, our model is small and these cells only compose a small part of CA3 interneurons, so we didn't consider these cells. If we expand the structure of our network, we'd better add these types of interneurons.

VPA is one of the major AEDs used today, and has high efficiency in treating various seizure types such as myoclonic, generalized tonic-clonic seizures and partial seizures $[25,42]$. In this work, the GABA-ergic inhibitory connection strength was enhanced and the NMDA-ergic excitatory connection strength was reduced to simulate the effects of VPA. However, VPA may also control epileptiform activities by affecting some ion channels. It has been reported that VPA may affect calcium and potassium channels by interfering with calcium entry into the cell and activating the potassium conductance, which lead to the reduction of neuronal excitability [25,43]. VPA may also inhibit sodium channels [44], although this opinion has been questioned [45]. In this model, we didn't consider the possible effects of VPA on these channels, which might make the simulated effects of VPA on epileptiform activities smaller than VPA's real effects.

In the future work, our model may be used to do other researches about epileptiform activities, such as the effects of 6-cyano-7-nitroquinoxaline-2,3-dione (CNQX) or 
bicuculline on the $\mathrm{Mg}^{2+}$-free-ACSF induced epileptiform discharges [24]. However, the model built here is very simple compared with what we have known of the CA3 field. To make the model more similar to the real CA3 network, the number of the pyramidal cells, basket cells and OLM cells in the model can be increased, and more cell types and their connectivity can be included in the future work.

\section{Methods}

\section{Network structure of the CA3 model}

The network structure of the CA3 model is illustrated in Figure 6. The network consists of 2 pyramidal cells, one OLM cell and one basket cell. Pyramidal cells excite each other, and they also excite the basket cell and OLM cell. The basket cell inhibits itself, the OLM cell and both pyramidal cells. The OLM cell inhibits both pyramidal cells. As shown in Figure 6, the simulated region receives 2 inputs from the EC and DG respectively. The input from the DG excites the proximal dendrite of one pyramidal cell and the input from the EC excites the distal dendrites of both pyramidal cells. Schematic representations of the simulated cells and their responses to current injections are described in Figure 5. The complete mathematical implementation of each cell is described in the Appendix. All simulations were performed using NEURON [29] running on a personal computer under Windows 7.

Basket cells and OLM cells are 2 commonest interneurons in the CA3 models [31,35-37]. It has been reported that interneurons that control the firing activities of pyramidal cells have 2 types: perisomatic-targeting interneurons and dendritic-targeting interneurons. Basket cells belong to the former type and OLM cells belong to the latter [37]. Basket cells control the synchrony of action potentials of pyramidal cells [46]. OLM cells affect the membrane potentials of dendrites of pyramidal cells, where most

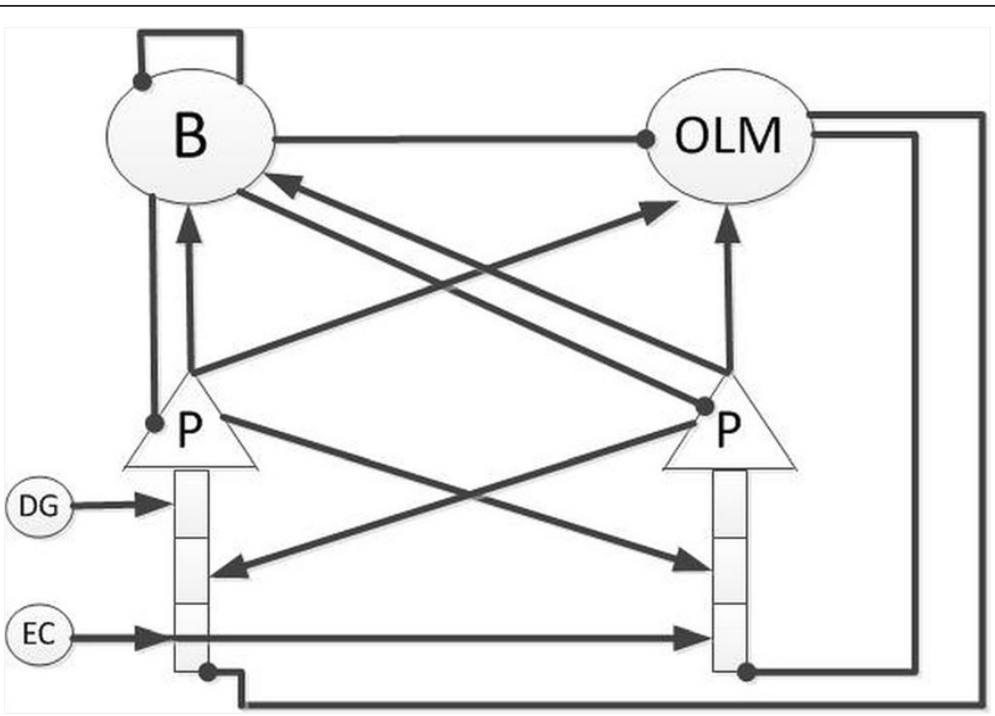

Figure 6 Simulated CA3 network. The basket cell (B) inhibits itself, the OLM cell (OLM) and the pyramidal cells (P). The OLM cell inhibits the distal dendrites of the pyramidal cells. Pyramidal cells excite each other and both inhibitory cells. The input from the DG excites the proximal dendrite of one pyramidal cell and the input from the EC excites the distal dendrites of both pyramidal cells. In this diagram, the filled circles represent inhibitory synapses, whereas the arrows represent excitatory synapses. 
glutamatergic receptors locate. As the conductance of glutamatergic receptors is related to the local membrane potentials $[47,48]$, OLM cells control the efficacy of glutamatergic inputs [46]. Hence changes in firing patterns of the basket and OLM cells may result in pathological forms of population synchrony, which may lead to epilepsy [46].

\section{Pyramidal cell}

Each simulated pyramidal cell consists of 4 compartments: one somatic and 3 dendritic compartments [36]. Each pyramidal cell contains leak current, sodium current, delayed rectifier potassium $\left(\mathrm{K}^{+}\right)$current, calcium $\left(\mathrm{Ca}^{2+}\right)$ activated $\mathrm{K}^{+}$current, afterhyperpolarization (AHP) $\mathrm{K}^{+}$current, $\mathrm{M}$-type $\mathrm{K}^{+}$current, L-type $\mathrm{Ca}^{2+}$ current, $\mathrm{N}$-type $\mathrm{Ca}^{2+}$ current, and T-type $\mathrm{Ca}^{2+}$ current $[24,31,39,41]$. The leak, sodium and delayed rectifier $\mathrm{K}^{+}$currents allow cells to generate action potentials [31]. The $\mathrm{Ca}^{2+}$-activated $\mathrm{K}^{+}$current and $\mathrm{AHP} \mathrm{K}^{+}$current make the cells have the property of spike-frequency adaptation, which has been observed in most pyramidal cells [49]. The M-type $\mathrm{K}^{+}$current plays an important role in the regulation of firing rate, and it has been reported that small changes of the $\mathrm{M}$ current seem to be sufficient to cause epileptic seizures [50]. Voltage-sensitive $\mathrm{Ca}^{2+}$ currents may contribute to epileptogenesis and the $\mathrm{N}$-type and L-type $\mathrm{Ca}^{2+}$ current have been revealed to regulate a number of neuronal processes, including $\mathrm{Ca}^{2+}$-dependent $\mathrm{K}^{+}$currents [51]. In addition, the T-type $\mathrm{Ca}^{2+}$ current can control the membrane potentials and intracellular $\mathrm{Ca}^{2+}$ concentrations [52]. The parameters of all ionic conductance used in the model are listed in Table 1. Sodium, delayed rectifier $\mathrm{K}^{+}, \mathrm{N}$-type $\mathrm{Ca}^{2+}$ and T-type $\mathrm{Ca}^{2+}$ conductance is uniformly distributed throughout the entire neuron, $\mathrm{Ca}^{2+}$-activated $\mathrm{K}^{+}$conductance decreases with distance from the soma, AHP $\mathrm{K}^{+}$conductance is lower in distal than in proximal dendrites, and $\mathrm{T}$-type $\mathrm{Ca}^{2+}$ conductance exists only in the soma and proximal dendrites. The distribution of the ionic conductance is similar with the

Table 1 Passive parameters and ionic conductance of channels for all compartments of pyramidal cells

\begin{tabular}{|c|c|c|c|c|}
\hline Mechanism & Soma & Prox dend & Med dend & Dist dend \\
\hline$\overline{C_{m}, \mu F / \mathrm{cm}^{2}}$ & 1 & 2 & 2 & 2 \\
\hline $\mathrm{R}_{\mathrm{m}}, \Omega \mathrm{cm}^{2}$ & 60000 & 30000 & 30000 & 30000 \\
\hline $\mathrm{Ra}, \Omega \mathrm{cm}$ & 200 & 200 & 200 & 200 \\
\hline Leak conductance $\left[\mathrm{S} / \mathrm{cm}^{2}\right]$ & 0.000017 & 0.000033 & 0.000033 & 0.000033 \\
\hline Sodium conductance $\left[S / \mathrm{cm}^{2}\right]$ & 0.035 & 0.035 & 0.035 & 0.035 \\
\hline Delayed rectifier $\mathrm{K}^{+}$conductance $\left[\mathrm{S} / \mathrm{cm}^{2}\right]$ & 0.005 & 0.005 & 0.005 & 0.005 \\
\hline $\mathrm{Ca}^{2+}$-activated $\mathrm{K}^{+}$conductance $\left[\mathrm{S} / \mathrm{cm}^{2}\right]$ & 0.003 & 0.00225 & 0.00075 & - \\
\hline AHP K ${ }^{+}$conductance $\left[\mathrm{S} / \mathrm{cm}^{2}\right]$ & 0.0009 & - & 0.000225 & 0.000225 \\
\hline M-type $\mathrm{K}^{+}$conductance $\left[\mathrm{S} / \mathrm{cm}^{2}\right]$ & 0 & 0.0023 & 0.00023 & 0.000023 \\
\hline L-type $\mathrm{Ca}^{2+}$ conductance $\left[\mathrm{S} / \mathrm{cm}^{2}\right]$ & 0.0014 & 0.0014 & - & - \\
\hline $\mathrm{N}$-type $\mathrm{Ca}^{2+}$ conductance $\left[\mathrm{S} / \mathrm{cm}^{2}\right]$ & 0.0016 & 0.0016 & 0.0016 & 0.0016 \\
\hline T-type $\mathrm{Ca}^{2+}$ conductance $\left[\mathrm{S} / \mathrm{cm}^{2}\right]$ & 0.0005 & 0.0005 & 0.0005 & 0.0005 \\
\hline$E_{L}(m V)$ & -65 & -65 & -65 & -65 \\
\hline $\mathrm{E}_{\mathrm{Na}}(\mathrm{mV})$ & 50 & 50 & 50 & 50 \\
\hline$E_{K}(m V)$ & -80 & -80 & -80 & -80 \\
\hline
\end{tabular}

$c_{m}$ : membrane capacity, $R_{m}$ : membrane resistivity, $R_{a}$ : intracellular resistivity, $E_{L}$ : equilibrium potential of the leak current, $E_{\mathrm{Na}}$ : equilibrium potential of the sodium current, $\mathrm{E}_{\mathrm{k}}$ : equilibrium potential of the $\mathrm{K}^{+}$current. 
parameters of a bursting model of the CA3 pyramidal cell built by Lazarewicz et al. [41]. Responses of the pyramidal cell to current injections are shown in Figure 5A. We can see that the pyramidal cell generates bursts, which have been revealed to be the ability most pyramidal cells in the CA3 region have during the application of somatic current injections $[4,5]$. In addition, the firing pattern of this pyramidal cell is similar to the pattern measured in experiments [39].

As suggested by the CA3 models built earlier [24,31,36,37] and anatomical studies $[21,38]$, each pyramidal cell receives somatic synaptic inhibition from the basket cell, distal apical inhibition from the OLM cell and medial dendritic excitation from the other pyramidal cell. It has been reported that the input from the DG projects proximally to the stratum lucidum, whereas the input from the EC projects distally to the stratum lacunosum-moleculare [36]. The input from the DG was relatively selective and projected to some of the CA3 pyramidal cells [36]. Thus, in our model, one pyramidal cell receives proximal excitation from the DG and both pyramidal cells receive distal excitation from the EC.

\section{Basket cell}

The simulated basket cell has one compartment $[31,36,37]$ and contains leak current, sodium current, and delayed rectifier $\mathrm{K}^{+}$current [31,53]. It is the same as the basket cell model built by Neymotin et al. [31]. It has been proven that basket cells are prevalent within the CA3 region [36], and they are fast-spiking interneurons [53]. With fast kinetics of the sodium current and delayed rectifier $\mathrm{K}^{+}$current, the basket cell has the ability to fire repetitive spikes at high frequencies (Figure 5B). As a consequence, compared to the OLM cell, the basket cell affects pyramidal cells with a higher frequency. The basket cell inhibits the somata of both pyramidal cells directly and simultaneously, which help to control the synchrony of action potentials of pyramidal cells [46]. The parameters of ionic conductance used in the model are listed in Table 2. According to the CA3 models built earlier [36,37] and anatomical studies [38], the basket cell receives excitatory inputs from pyramidal cells and the inhibitory input from itself.

\section{OLM cell}

The simulated OLM cell has one compartment $[31,36,37]$ and contains leak current, sodium current, delayed rectifier $\mathrm{K}^{+}$current, $\mathrm{Ca}^{2+}$-activated $\mathrm{K}^{+}$current, $\mathrm{Ca}^{2+}$ current, and hyperpolarization-activated current $\mathrm{I}_{\mathrm{h}}[31,54]$. The $\mathrm{Ca}^{2+}$-activated $\mathrm{K}^{+}$current allows the cells to have long lasting inactivation after bursting [31], and as well as $\mathrm{Ca}^{2+}$ current, help the cells to produce spike-frequency adaptation [54]. The OLM cell also has hyperpolarization-activated current $I_{h}$ for bursting [31]. The OLM cell projects to the dendrites of both pyramidal cells in the model, and affects the membrane potentials there. As glutamatergic receptors locate in the dendrites of pyramidal cells and their conductance is related to the local membrane potentials $[47,48]$, the OLM cell controls the efficacy of glutamatergic receptors, which affects $\mathrm{Mg}^{2+}$-free-ACSF induced epileptiform activities. The parameters of ionic conductance used in the model are listed in Table 2, which are the same as the parameters used by Wang [54]. According to anatomical studies, the OLM cell receives excitatory inputs from pyramidal cells and the inhibitory input from the basket cell $[37,38]$. 
Table 2 Passive parameters and ionic conductance of channels for all compartments of basket and OLM cells

\begin{tabular}{|c|c|c|}
\hline Mechanism & Basket cell & OLM cell \\
\hline$\overline{C_{m}, \mu F / \mathrm{cm}^{2}}$ & 1 & 1 \\
\hline $\mathrm{R}_{\mathrm{m}}, \Omega \mathrm{cm}^{2}$ & 60000 & 60000 \\
\hline $\mathrm{Ra}, \Omega \mathrm{cm}$ & 200 & 200 \\
\hline Leak conductance $\left[\mathrm{S} / \mathrm{cm}^{2}\right]$ & 0.000017 & 0.000017 \\
\hline Sodium conductance $\left[\mathrm{S} / \mathrm{cm}^{2}\right]$ & 0.035 & 0.035 \\
\hline Delayed rectifier $\mathrm{K}^{+}$conductance $\left[\mathrm{S} / \mathrm{cm}^{2}\right]$ & 0.0009 & 0.0009 \\
\hline $\mathrm{Ca}^{2+}$-activated $\mathrm{K}^{+}$conductance $\left[\mathrm{S} / \mathrm{cm}^{2}\right]$ & - & 0.01 \\
\hline $\mathrm{Ca}^{2+}$-activated $\left[\mathrm{S} / \mathrm{cm}^{2}\right]$ & - & 0.001 \\
\hline $\mathrm{I}_{\mathrm{h}}$ conductance $\left[\mathrm{S} / \mathrm{cm}^{2}\right]$ & - & 0.15 \\
\hline$E_{L}(m V)$ & -65 & -65 \\
\hline $\mathrm{E}_{\mathrm{Na}}(\mathrm{mV})$ & 66 & 55 \\
\hline$E_{K}(m V)$ & -90 & -90 \\
\hline $\mathrm{E}_{\mathrm{Ca}}(\mathrm{mV})$ & - & 120 \\
\hline$E_{h}(m V)$ & - & -40 \\
\hline
\end{tabular}

\section{Synaptic properties}

In this model, AMPA, NMDA and $\mathrm{GABA}_{\mathrm{A}}$ receptors are considered, which are the commonest receptors in CA3 models [31,35]. As the network built here is small, AMPA and NMDA receptors are present in all excitatory connections, and $\mathrm{GABA}_{\mathrm{A}}$ receptors are present in all inhibitory connections. AMPA and $\mathrm{GABA}_{\mathrm{A}}$ receptors are modelled by a standard NEURON double-exponential mechanism $[47,48]$. The synaptic conductance $\mathrm{g}_{\text {syn }}(\mathrm{t})$ is given by:

$$
g_{\text {syn }}(t)=c^{*}\left[\exp \left(-\frac{t}{\tau_{2}}\right)-\exp \left(-\frac{t}{\tau_{1}}\right)\right]
$$

where $\mathrm{c}$ is the weight, $\tau_{1}$ is the rising time constant, and $\tau_{2}$ is the falling time constant. The NMDA receptor conductance is dependent on the local membrane potential and the external $\mathrm{Mg}^{2+}$ concentration [31,47], and it is given by:

$$
g_{\text {syn }}(t)=c^{*} \frac{\exp \left(-\frac{t}{\tau_{2}}\right)-\exp \left(-\frac{t}{\tau_{1}}\right)}{1+\frac{M g}{3.57} \exp (-0.062 V(t))}
$$

where $\mathrm{Mg}$ is the external $\mathrm{Mg}^{2+}$ concentration in $\mathrm{mM}, \mathrm{V}(\mathrm{t})$ is the local membrane potential in $\mathrm{mV}$, and the other variables are as in eq. (1). AMPA and NMDA receptors have reversal potentials of $0 \mathrm{mV}$, while $\mathrm{GABA}_{\mathrm{A}}$ receptors have reversal potentials of $-80 \mathrm{mV}$ [31]. The parameters of synapses are present in Table 3 , which are based on the model built by Neymotin et al. [31].

\section{Model inputs}

The model receives two extrahippocampal inputs from the DG and EC respectively. The input from the DG projects to the proximal dendrites of pyramidal cells, whereas 
Table 3 Synaptic parameters

\begin{tabular}{lllccc}
\hline Presynaptic & Postsynaptic & Receptor & $\mathbf{T}_{\mathbf{1}}(\mathbf{m s})$ & $\mathbf{T}_{\mathbf{2}}(\mathbf{m s})$ & Conductance $(\boldsymbol{\mu S})$ \\
\hline Pyramidal & Pyramidal & AMPA & 0.05 & 15.3 & 0.00045 \\
Pyramidal & Pyramidal & NMDA & 15 & 150 & 0.00036 \\
Pyramidal & Basket & AMPA & 0.05 & 5.3 & 0.18 \\
Pyramidal & Basket & NMDA & 15 & 150 & 0.36 \\
Pyramidal & OLM & AMPA & 0.05 & 5.3 & 0.18 \\
Pyramidal & OLM & AMPA & 15 & 150 & 0.36 \\
Basket & Pyramidal & GABA & 0.07 & 9.1 & 0.13 \\
Basket & Basket & GABA & 0.07 & 9.1 & 0.65 \\
Basket & OLM & GABA & 20 & 40 & 0.39 \\
OLM & Pyramidal & GABA & 0.2 & 20 & 1.3 \\
DG & Pyramidal & AMPA & 0.05 & 5.3 & 0.0036 \\
DG & Pyramidal & NMDA & 15 & 150 & 0.0012 \\
EC & Pyramidal & AMPA & 0.05 & 5.3 & 0.00036 \\
EC & Pyramidal & NMDA & 15 & 150 & 0.000072 \\
\hline
\end{tabular}

the input from the EC projects distally to the dendrites of pyramidal cells [55]. In the simulation, the input from the DG was relatively strong and selective, exciting only one of the pyramidal cells. However, the input from the EC was relatively weak and diffuse, exciting both pyramidal cells $[21,36,55]$. As suggested by the data from experiments, interictal discharges were induced by $\mathrm{Mg}^{2+}$-free-ACSF in hippocampal slices, and CA3 were considered to be the initiation place $[16,18,19]$. As hippocampal slices didn't contain EC, we only considered the input from the DG, which followed a Possion process $(\lambda=1)$ in the model [31]. In combined EC-hippocampal slices, alternate interictal and ictal discharges were induced by $\mathrm{Mg}^{2+}$-free-ACSF, and epileptiform activities in the EC and DG were synchronized with each other $[18,19]$. An extral pyramidal cell was built, which received current injections and generated ictal-like and interictal-like discharges, to simulate the input signals from the DG and EC. AMPA and NMDA receptors were presented in all the connections, and the connection strength between the input from the DG and the model was larger than that between the input from the EC and the model.

\section{Appendix}

\section{Pyramidal cell}

The somatic (s), proximal dendritic (pd), medium dendritic (md), and distal dendritic (dd) compartments obey the following current balance equations:

$$
\begin{aligned}
& c \frac{d V_{s}}{d t}=-I_{L}-I_{N a}-I_{k d r}-I_{k c}-I_{A H P}-I_{k m}-I_{C a L}-I_{C a N}-I_{C a T}-I_{s y n} \\
& c \frac{d V_{p d}}{d t}=-I_{L}-I_{N a}-I_{k d r}-I_{k c}-I_{k m}-I_{C a L}-I_{C a N}-I_{C a T}-I_{s y n} \\
& c \frac{d V_{m d}}{d t}=-I_{L}-I_{N a}-I_{k d r}-I_{k c}-I_{A H P}-I_{k m}-I_{C a N}-I_{C a T}-I_{\text {syn }} \\
& c \frac{d V_{d d}}{d t}=-I_{L}-I_{N a}-I_{k d r}-I_{A H P}-I_{k m}-I_{C a N}-I_{C a T}-I_{\text {syn }}
\end{aligned}
$$

Where $I_{L}$ is the leak current, $I_{N a}$ is the sodium current, $I_{k d r}$ is the delayed rectifier $K^{+}$ current, $\mathrm{I}_{\mathrm{kc}}$ is the $\mathrm{Ca}^{2+}$ activated $\mathrm{K}^{+}$current, $\mathrm{I}_{\mathrm{AHP}}$ is the AHP $\mathrm{K}^{+}$current, $\mathrm{I}_{\mathrm{km}}$ is the 
M-type $\mathrm{K}^{+}$current, $\mathrm{I}_{\mathrm{CaL}}, \mathrm{I}_{\mathrm{CaN}}$, and $\mathrm{I}_{\mathrm{CaT}}$ are the $\mathrm{L}$-, $\mathrm{N}$ - and $\mathrm{T}$-type $\mathrm{Ca}^{2+}$ currents, and $\mathrm{I}_{\text {syn }}$ is the synaptic current. The conductance and reversal potential values for all ionic currents are listed in Table 1.

The sodium current is described by [56]:

$$
\begin{aligned}
& \mathrm{I}_{\mathrm{Na}}=\mathrm{g}_{\mathrm{Na}} \mathrm{m}^{3} \mathrm{~h}\left(\mathrm{~V}-\mathrm{E}_{\mathrm{Na}}\right) \\
& \alpha_{\mathrm{m}}=\frac{0.32(13.1-\mathrm{V})}{\exp \left(\frac{13.1-\mathrm{V}}{4}\right)-1} \\
& \beta_{\mathrm{m}}=\frac{0.28(\mathrm{~V}-40.1)}{\exp \left(\frac{\mathrm{V}-40.1}{5}\right)-1} \\
& \alpha_{\mathrm{h}}=0.128 \exp \left(\frac{17-\mathrm{V}}{18}\right) \\
& \beta_{\mathrm{h}}=\frac{4}{1+\exp \left(\frac{40-\mathrm{V}}{5}\right)}
\end{aligned}
$$

The $\mathrm{K}^{+}$currents are given by [39]:

$$
\begin{aligned}
& \mathrm{I}_{\mathrm{kdr}}=\mathrm{g}_{\mathrm{kdr}} \mathrm{m}^{3} \mathrm{~h}\left(\mathrm{~V}-\mathrm{E}_{\mathrm{k}}\right) \\
& \alpha_{\mathrm{m}}=0.03 \exp \left[2(\mathrm{~V}+32) * \frac{\mathrm{F}}{\mathrm{RT}}\right] \\
& \beta_{\mathrm{m}}=0.03 \exp \left[3(\mathrm{~V}+32) * \frac{\mathrm{F}}{\mathrm{RT}}\right] \\
& \alpha_{\mathrm{h}}=0.001 \exp \left[-2(\mathrm{~V}+61) * \frac{\mathrm{F}}{\mathrm{RT}}\right] \\
& \beta_{\mathrm{h}}=0.001 \\
& \mathrm{I}_{\mathrm{km}}=\mathrm{g}_{\mathrm{km}} \mathrm{m}\left(\mathrm{V}-\mathrm{E}_{\mathrm{k}}\right) \\
& \alpha_{\mathrm{m}}=0.006 \exp \left[0.6(\mathrm{~V}+55) * \frac{\mathrm{F}}{\mathrm{RT}}\right] \\
& \beta_{\mathrm{m}}=0.06 \exp \left[-9.4(\mathrm{~V}+55) * \frac{\mathrm{F}}{\mathrm{RT}}\right] \\
& \mathrm{I}_{\mathrm{AHP}}=\mathrm{g}_{\mathrm{AHP}} \mathrm{m}\left(\mathrm{V}-\mathrm{E}_{\mathrm{k}}\right) \\
& \alpha_{\mathrm{m}}=1.3 * 10^{13} *\left[\mathrm{Ca}^{2+}\right]_{\mathrm{i}}^{4} \\
& \beta_{\mathrm{m}}=0.005 \\
& \mathrm{I}_{\mathrm{kc}}=\mathrm{g}_{\mathrm{kc}} \mathrm{m}\left(\mathrm{V}-\mathrm{E}_{\mathrm{k}}\right) \\
& \alpha_{\mathrm{m}}=\frac{0.28\left[\mathrm{Ca}^{2+}\right]_{\mathrm{i}}}{\left[\mathrm{Ca}^{2+}\right]_{\mathrm{i}}+0.48 * 10^{-3} * \exp \left(-1.68 \mathrm{~V} * \frac{\mathrm{F}}{\mathrm{RT}}\right)} \\
& \beta \mathrm{m}=\frac{0.48}{1+\frac{\left[\mathrm{Ca}^{2+}\right]_{\mathrm{i}}}{0.13 * 10^{-6} * \exp \left(-2 \mathrm{~V} * \frac{\mathrm{F}}{\mathrm{RT}}\right)}}
\end{aligned}
$$


The $\mathrm{Ca}^{2+}$ currents are given by [57]:

$$
\begin{aligned}
& \mathrm{I}_{\mathrm{CaL}}=-\mathrm{g}_{\mathrm{CaL}} \mathrm{m}^{2} \mathrm{~V} \frac{1-\frac{\left[\mathrm{Ca}^{2+}\right]_{\mathrm{i}}}{\left[\mathrm{Ca}^{2+}\right]_{\mathrm{o}}} \exp \left(2 \mathrm{~V} * \frac{\mathrm{F}}{\mathrm{kT}}\right)}{1-\exp \left(2 \mathrm{~V} * \frac{\mathrm{F}}{\mathrm{kT}}\right)} \\
& \alpha_{\mathrm{m}}=\frac{15.69(81.5-\mathrm{V})}{\exp \left(\frac{81.5-\mathrm{V}}{10}\right)-1} \\
& \beta_{\mathrm{m}}=0.29 \exp \left(\frac{-\mathrm{V}}{10.86}\right) \\
& \mathrm{I}_{\mathrm{CaN}}=-\mathrm{g}_{\mathrm{CaN}} \mathrm{m}^{2} \mathrm{hV} \frac{1-\frac{\left[\mathrm{Ca}^{2+}\right]_{\mathrm{i}}}{\left[\mathrm{Ca}^{2+}\right]_{\mathrm{o}}} \exp \left(2 \mathrm{~V} * \frac{\mathrm{F}}{\mathrm{kT}}\right)}{1-\exp \left(2 \mathrm{~V} * \frac{\mathrm{F}}{\mathrm{kT}}\right)} \\
& \alpha_{\mathrm{m}}=\frac{0.19(19.88-\mathrm{V})}{\exp \left(\frac{19.88-\mathrm{V}}{10}\right)-1} \\
& \beta_{\mathrm{m}}=0.046 \exp \left(\frac{-\mathrm{V}}{20.73}\right) \\
& \alpha_{\mathrm{h}}=1.6 * 10^{-4} \exp \left(\frac{-\mathrm{V}}{48.4}\right) \\
& \beta_{\mathrm{h}}=\frac{1}{\exp \left(\frac{39-\mathrm{V}}{10}\right)+1} \\
& \mathrm{I}_{\mathrm{CaT}}=-\mathrm{g}_{\mathrm{CaT}} \mathrm{m}^{2} \mathrm{hV} \frac{1-\frac{\left[\mathrm{Ca}^{2+}\right]_{\mathrm{i}}}{\left[\mathrm{Ca}^{2+}\right]_{\mathrm{o}}} \exp \left(2 \mathrm{~V} * \frac{\mathrm{F}}{\mathrm{kT}}\right)}{1-\exp \left(2 \mathrm{~V} * \frac{\mathrm{F}}{\mathrm{kT}}\right)} \\
& \alpha_{\mathrm{m}}=\frac{0.2(19.26-\mathrm{V})}{\exp \left(\frac{19.26-\mathrm{V}}{10}\right)-1} \\
& \beta_{\mathrm{m}}=0.009 \exp \left(\frac{-\mathrm{V}}{22.03}\right) \\
& \alpha_{\mathrm{h}}=1.0 * 10^{-6} \exp \left(\frac{-\mathrm{V}}{16.26}\right) \\
& \beta_{\mathrm{h}}=\frac{1}{\exp \left(\frac{29.79-\mathrm{V}}{10}\right)+1}
\end{aligned}
$$

Where $\left[\mathrm{Ca}^{2+}\right]_{\mathrm{o}}=2 \mathrm{mM}$, resting $\left[\mathrm{Ca}^{2+}\right]_{\mathrm{i}}=50 \mathrm{nM}$, and the dynamics of $\left[\mathrm{Ca}^{2+}\right]_{\mathrm{i}}$ come from Migliore et al. [39].

In all the equations above, $\mathrm{V}$ is the membrane potential, $\mathrm{k}$ is the Boltzmann's constant, $F$ is the Faraday's constant, $T$ is the absolute temperature, $R$ is the gas constant, $\left[\mathrm{Ca}^{2+}\right]_{i}$ is 
the intracellular $\mathrm{Ca}^{2+}$ concentration, and $\left[\mathrm{Ca}^{2+}\right]_{\mathrm{o}}$ is the extracellular $\mathrm{Ca}^{2+}$ concentration. State variables $\mathrm{m}$ and $\mathrm{h}$ obey the following equations:

$$
\begin{aligned}
& \frac{\mathrm{dm}}{\mathrm{dt}}=\alpha_{\mathrm{m}}(1-\mathrm{m})-\beta_{\mathrm{m}} \mathrm{m} \\
& \frac{\mathrm{dh}}{\mathrm{dt}}=\alpha_{\mathrm{h}}(1-\mathrm{h})-\beta_{\mathrm{h}} \mathrm{h}
\end{aligned}
$$

\section{Basket cell}

The somatic compartment obeys the following current balance equation:

$$
\mathrm{c} \frac{\mathrm{dV}}{\mathrm{dt}}=-\mathrm{I}_{\mathrm{L}}-\mathrm{I}_{\mathrm{Na}}-\mathrm{I}_{\mathrm{kdr}}-\mathrm{I}_{\mathrm{syn}}
$$

Where $I_{L}$ is the leak current, $I_{N a}$ is the sodium current, $I_{k d r}$ is the delayed rectifier $K^{+}$ current, and $\mathrm{I}_{\text {syn }}$ is the synaptic current. The conductance and reversal potential values for all ionic currents are listed in Table 2. The model built here is the same as that built by Neymotin et al. [31].

The sodium current is described by:

$$
\begin{aligned}
& \mathrm{I}_{\mathrm{Na}}=\mathrm{g}_{\mathrm{Na}} \mathrm{m}^{3} \mathrm{~h}\left(\mathrm{~V}-\mathrm{E}_{\mathrm{Na}}\right) \\
& \alpha_{\mathrm{m}}=-\frac{0.1(\mathrm{~V}+35)}{\exp (-0.1(\mathrm{~V}+35))-1} \\
& \beta_{\mathrm{m}}=4 \exp \left(-\frac{\mathrm{V}+60}{18}\right) \\
& \alpha_{\mathrm{h}}=0.35 \exp \left(-\frac{\mathrm{V}+58}{20}\right) \\
& \beta_{\mathrm{h}}=\frac{\exp (-0.1(\mathrm{~V}+28))+1}{\exp }
\end{aligned}
$$

The delayed rectifier $\mathrm{K}^{+}$current is given by:

$$
\begin{aligned}
\mathrm{I}_{\mathrm{kdr}} & =\mathrm{g}_{\mathrm{kdr}} \mathrm{m}^{4}\left(\mathrm{~V}-\mathrm{E}_{\mathrm{k}}\right) \\
\alpha_{\mathrm{m}} & =-0.05(\mathrm{~V}+34) /(\exp (-0.1(\mathrm{~V}+34))-1) \\
\beta_{\mathrm{m}} & =0.625 \exp \left(-\frac{\mathrm{V}+44}{80}\right)
\end{aligned}
$$

In all the equations above, $\mathrm{V}$ is the membrane potential, State variables $\mathrm{m}$ and $\mathrm{h}$ obey the following equations:

$$
\begin{aligned}
& \frac{\mathrm{dm}}{\mathrm{dt}}=\alpha_{\mathrm{m}}(1-\mathrm{m})-\beta_{\mathrm{m}} \mathrm{m} \\
& \frac{\mathrm{dh}}{\mathrm{dt}}=\alpha_{\mathrm{h}}(1-\mathrm{h})-\beta_{\mathrm{h}} \mathrm{h}
\end{aligned}
$$

\section{OLM cell}

The somatic compartment obeys the following current balance equation:

$$
\mathrm{c} \frac{\mathrm{dV}}{\mathrm{dt}}=-\mathrm{I}_{\mathrm{L}}-\mathrm{I}_{\mathrm{Na}}-\mathrm{I}_{\mathrm{kdr}}-\mathrm{I}_{\mathrm{h}}-\mathrm{I}_{\mathrm{Ca}}-\mathrm{I}_{\mathrm{kc}}-\mathrm{I}_{\mathrm{syn}}
$$


Where $\mathrm{I}_{\mathrm{L}}$ is the leak current, $\mathrm{I}_{\mathrm{Na}}$ is the sodium current, $\mathrm{I}_{\mathrm{kdr}}$ is the delayed rectifier $\mathrm{K}^{+}$ current, $\mathrm{I}_{\mathrm{h}}$ is the hyperpolarization-activated current, $\mathrm{I}_{\mathrm{Ca}}$ is the $\mathrm{Ca}^{2+}$ current, $\mathrm{I}_{\mathrm{kc}}$ is the $\mathrm{Ca}^{2+}$ activated $\mathrm{K}^{+}$current, and $\mathrm{I}_{\text {syn }}$ is the synaptic current. In this model, the sodium current $\mathrm{I}_{\mathrm{Na}}$ and the delayed rectifier $\mathrm{K}^{+}$current $\mathrm{I}_{\mathrm{kdr}}$ are the same as in the basket cell. The conductance and reversal potential values for all ionic currents are listed in Table 2. The model built here is the same as that built by Wang [54].

The $\mathrm{h}$ current is described by:

$$
\begin{aligned}
& \mathrm{I}_{\mathrm{h}}=\mathrm{g}_{\mathrm{h}} \mathrm{n}\left(\mathrm{V}-\mathrm{E}_{\mathrm{h}}\right) \\
& \mathrm{n}_{\infty}=1 /\left(1+\exp \left(\frac{\mathrm{V}+80}{10}\right)\right) \\
& \mathrm{\tau}_{\mathrm{n}}=\frac{200}{\exp \left(\frac{\mathrm{V}+70}{20}\right)+\exp \left(-\frac{\mathrm{V}+70}{20}\right)}+5 \\
& \mathrm{n}_{\infty}=\frac{\alpha_{\mathrm{n}}}{\alpha_{\mathrm{n}}+\beta_{\mathrm{n}}} \\
& \tau_{\mathrm{n}}=\frac{1}{\alpha_{\mathrm{n}}+\beta_{\mathrm{n}}} \\
& \frac{\mathrm{dn}}{\mathrm{dt}}=\alpha_{\mathrm{n}}(1-\mathrm{n})-\beta_{\mathrm{n}} \mathrm{n}
\end{aligned}
$$

The $\mathrm{Ca}^{2+}$ current is given by:

$$
\begin{aligned}
& \mathrm{I}_{\mathrm{Ca}}=\mathrm{g}_{\mathrm{Ca}} \mathrm{m}_{\infty}^{2}\left(\mathrm{~V}-\mathrm{E}_{\mathrm{Ca}}\right) \\
& \mathrm{m}_{\infty}=1 /\left(1+\exp \left(-\frac{(\mathrm{V}+20)}{9}\right)\right)
\end{aligned}
$$

Where $\mathrm{m}$ is replaced by its steady-state $\mathrm{m}_{\infty}$.

The $\mathrm{Ca}^{2+}$ activated $\mathrm{K}^{+}$current is given by:

$$
\begin{aligned}
& \mathrm{I}_{\mathrm{kc}}=\mathrm{g}_{\mathrm{kc}} \frac{\left[\mathrm{Ca}^{2+}\right]_{\mathrm{i}}}{\left[\mathrm{Ca}^{2+}\right]_{\mathrm{i}}+30}\left(\mathrm{~V}-\mathrm{E}_{\mathrm{k}}\right) \\
& \frac{\mathrm{d}\left[\mathrm{Ca}^{2+}\right]_{\mathrm{i}}}{\mathrm{dt}}=-0.002 \mathrm{I}_{\mathrm{Ca}}-\left[\mathrm{Ca}^{2+}\right]_{\mathrm{i}} / 80
\end{aligned}
$$

In all the equations above, $\mathrm{V}$ is the membrane potential, $\left[\mathrm{Ca}^{2+}\right]_{\mathrm{i}}$ is the intracellular $\mathrm{Ca}^{2+}$ concentration.

Competing interests

The authors declare that they have no competing interests.

\section{Authors' contributions}

HR built the model and drafted the manuscript, YJS did the experiments, PMZ and QCL instructed the experiments, PMZ and PJL improved the model, PMZ improved the manuscript. All authors read and approved the final manuscript.

\section{Acknowledgments}

This work was supported by the Key Basic Research Project of Science and Technology Commission of Shanghai (13DJ1400303), the Natural Science Foundation of Shanghai (12ZR1413800), the Shanghai Jiao Tong University Fund for Interdisciplinary Research for Medical Applications (YG2012ZD08), and the Seed Fund of Ren Ji Hospital (RJZZ13-005).

\section{Author details}

${ }^{1}$ School of Biomedical Engineering, Shanghai Jiao Tong University, Shanghai 200240, China. ${ }^{2}$ Department of Neurology, Ren Ji Hospital, School of Medicine, Shanghai Jiao Tong University, Shanghai 200127, China. 


\section{References}

1. Schmidt D, Loscher W: Drug resistance in epilepsy: putative neurobiologic and clinical mechanisms. Epilepsia 2005, 46:858-877.

2. Bertram EH: Temporal lobe epilepsy: where do the seizures really begin? Epilepsy Behav 2009, 14:32-37.

3. Jefferys JG: Models and mechanisms of experimental epilepsies. Epilepsia 2003, 44:44-50.

4. McCormick DA, Contreras D: On the cellular and network bases of epileptic seizures. Annu Rev Physiol 2001, 63:815-846

5. MCNamara JO: Cellular and molecular basis of epilepsy. J Neurosci 1994, 14:3413-3425

6. Avoli M, D'Antuono M, Louvel J, Kohling R, Biagini G, Pumain R, D'Arcangelo G, Tancredi V: Network and pharmacological mechanisms leading to epileptiform synchronization in the limbic system in vitro. Prog Neurobiol 2002, 68:167-207.

7. Jutila L, Ylinen A, Partanen K, Alafuzoff I, Mervaala E, Partanen J, Vapalahti M, Vainio P, Pitkanen A: MR volumetry of the entorhinal, perirhinal, and temporopolar cortices in drug-refractory temporal lobe epilepsy. AJNR Am J Neuroradiol 2001, 22:1490-1501.

8. Du F, Eid T, Lothman EW, Kohler C, Schwarcz R: Preferential neuronal loss in layer III of the medial entorhinal cortex in rat models of temporal lobe epilepsy. J Neurosci 1995, 15:6301-6313.

9. Du F, Whetsell WO Jr, Abou-Khalil B, Blumenkopf B, Lothman EW, Schwarcz R: Preferential neuronal loss in layer III of the entorhinal cortex in patients with temporal lobe epilepsy. Epilepsy Res 1993, 16:223-233.

10. Bartolomei F, Khalil M, Wendling F, Sontheimer A, Regis J, Ranjeva JP, Guye M, Chauvel P: Entorhinal cortex involvement in human mesial temporal lobe epilepsy: an electrophysiologic and volumetric study. Epilepsia 2005, 46:677-687.

11. de Curtis M, Jefferys JGR, Avoli M: Interictal Epileptiform Discharges in Partial Epilepsy: Complex Neurobiological Mechanisms Based on Experimental and Clinical Evidence. In Jasper's Basic Mechanisms of the Epilepsies [Internet]; 2012.

12. Charpak $S$, Pare D, Llinas $R$ : The entorhinal cortex entrains fast CA1 hippocampal oscillations in the anaesthetized guinea-pig: role of the monosynaptic component of the perforant path. Eur J Neurosci 1995, 7:1548-1557.

13. Kumar SS, Jin X, Buckmaster PS, Huguenard JR: Recurrent circuits in layer II of medial entorhinal cortex in a model of temporal lobe epilepsy. J Neurosci 2007, 27:1239-1246.

14. Nagao T, Alonso A, Avoli M: Epileptiform activity induced by pilocarpine in the rat hippocampal-entorhinal slice preparation. Neuroscience 1996, 72:399-408.

15. Yang F, Gong XW, Gong HQ, Zhang PM, Liang PJ, Lu QC: Microelectrode array recording of excitability of low Mg2+-induced acute hippocampal slices. Neural Regeneration Research 2010, 5:1548-1551.

16. Gong XW, Yang F, Liu JS, Lu QC, Gong HQ, Liang PJ, Zhang PM: Investigation of The Initiation Site and Propagation of Epileptiform Discharges in Hippocampal Slices Using Microelectrode Array. Progress Biochem Biophys 2010, 37:1240-1247.

17. Li JB, Lu QC, Gong XW, Gong HQ, Zhang PM, Liang PJ: The Modulatory Effects of Exogenous $\mathrm{Zn}^{2+}$ on Propagation and Frequency of Epileptiform Discharges on Rat Hippocampal Slices. Acta Biophysica Sinica 2012 2:119-130.

18. Shi YJ, Lu QC, Gong XW, Gong HQ, Zhang PM, Liang PJ: Comparative study of the characteristics of epileptiform discharges in the hippocampal slices and combined entorhinal cortex-hippocampal slices. Chinese J Clin (Electronic Edition) 2013, 7:5397-5400.

19. Shi YJ, Gong XW, Gong HQ, Liang PJ, Zhang PM, Lu QC: Effect of the entorhinal cortex on ictal discharges in low-Mg2+-induced epileptic hippocampal slice models. Neural Plasticity 2014. doi:10.1155/2014/205912.

20. Jefferys JGR, Jiruska P, de Curtis M, Avoli M: Limbic Network Synchronization and Temporal Lobe Epilepsy. In Jasper's Basic Mechanisms of the Epilepsies [Internet]. 2012.

21. Andersen P, Morris R, Amaral D, Bliss T, O'Keefe J: The hippocampus book. Oxford University Press; 2007.

22. Traub RD, Miles R, Buzsaki $\mathrm{G}$ : Computer simulation of carbachol-driven rhythmic population oscillations in the CA3 region of the in vitro rat hippocampus. J Physiol 1992, 451:653-672.

23. Traub RD, Miles R, Jefferys JG: Synaptic and intrinsic conductances shape picrotoxin-induced synchronized after-discharges in the guinea-pig hippocampal slice. J Physiol 1993, 461:525-547.

24. Traub RD, Jefferys JG, Whittington MA: Enhanced NMDA conductance can account for epileptiform activity induced by low Mg2+ in the rat hippocampal slice. J Physiol 1994, 478:379-393.

25. Johannessen CU, Johannessen SI: Valproate: past, present, and future. CNS Drug Rev 2003, 9:199-216.

26. Bruckner $C$, Heinemann U: Effects of standard anticonvulsant drugs on different patterns of epileptiform discharges induced by 4-aminopyridine in combined entorhinal cortex-hippocampal slices. Brain Res 2000 859:15-20.

27. D'Antuono M, Kohling R, Ricalzone S, Gotman J, Biagini G, Avoli M: Antiepileptic drugs abolish ictal but not interictal epileptiform discharges in vitro. Epilepsia 2010, 51:423-431.

28. Fueta Y, Avoli M: Effects of antiepileptic drugs on 4-aminopyridine-induced epileptiform activity in young and adult rat hippocampus. Epilepsy Res 1992, 12:207-215.

29. Hines ML, Carnevale NT: The NEURON simulation environment. Neural Comput 1997, 9:1179-1209.

30. Lopantsev V, Avoli M: Participation of GABAA-mediated inhibition in ictallike discharges in the rat entorhinal cortex. J Neurophysiol 1998, 79:352-360

31. Neymotin SA, Lazarewicz MT, Sherif M, Contreras D, Finkel LH, Lytton WW: Ketamine disrupts theta modulation of gamma in a computer model of hippocampus. J Neurosci 2011, 31:11733-11743.

32. Jonas P, Major G, Sakmann B: Quantal components of unitary EPSCs at the mossy fibre synapse on CA3 pyramidal cells of rat hippocampus. J Physiol 1993, 472:615-663. 
33. Rutecki PA: Noradrenergic modulation of epileptiform activity in the hippocampus. Epilepsy Res 1995, 20:125-136.

34. Froriep UP, Kumar A, Cosandier-Rimele D, Haussler U, Kilias A, Haas CA, Egert U: Altered theta coupling between medial entorhinal cortex and dentate gyrus in temporal lobe epilepsy. Epilepsia 2012, 53:1937-1947.

35. Stanley DA, Talathi SS, Parekh MB, Cordiner DJ, Zhou J, Mareci TH, Ditto WL, Carney PR: Phase shift in the 24-hour rhythm of hippocampal EEG spiking activity in a rat model of temporal lobe epilepsy. J Neurophysiol 2013, 110:1070-1086.

36. Kunec S, Hasselmo ME, Kopell N: Encoding and retrieval in the CA3 region of the hippocampus: a model of theta-phase separation. J Neurophysiol 2005, 94:70-82.

37. Tort ABL, Rotstein HG, Dugladze T, Gloveli T, Kopell NJ: On the formation of gamma-coherent cell assemblies by oriens lacunosum-moleculare interneurons in the hippocampus. Proc Natl Acad Sci USA 2007, 104:13490-13495.

38. Freund TF, Buzsaki G: Interneurons of the hippocampus. Hippocampus 1996, 6:347-470

39. Migliore $M$, Cook EP, Jaffe DB, Turner DA, Johnston D: Computer simulations of morphologically reconstructed CA3 hippocampal neurons. J Neurophysiol 1995, 73:1157-1168.

40. Yaari Y, Beck H: "Epileptic neurons" in temporal lobe epilepsy. Brain Pathol 2002, 12:234-239.

41. Lazarewicz MT, Migliore M, Ascoli GA: A new bursting model of CA3 pyramidal cell physiology suggests multiple locations for spike initiation. Biosystems 2002, 67:129-137.

42. Johannessen CU: Mechanisms of action of valproate: a commentatory. Neurochem Int 2000, 37:103-110

43. Franceschetti S, Hamon B, Heinemann U: The action of valproate on spontaneous epileptiform activity in the absence of synaptic transmission and on evoked changes in [Ca2+]o and [K+]o in the hippocampal slice. Brain Res 1986, 386:1-11.

44. Yamamoto R, Yanagita T, Kobayashi H, Yokoo H, Wada A: Up-regulation of sodium channel subunit mRNAs and their cell surface expression by antiepileptic valproic acid: activation of calcium channel and catecholamine secretion in adrenal chromaffin cells. J Neurochem 1997, 68:1655-1662.

45. Loscher W: Valproate: a reappraisal of its pharmacodynamic properties and mechanisms of action. Prog Neurobiol 1999, 58:31-59.

46. Parekh R: Interactions between oriens, basket and pyramidal cells during in vitro seizure-like events in CA1 of the rat hippocampus. Dissertation of Philosophy Doctor, Pennsylvania State University; 2010.

47. Baker JL, Perez-Rosello T, Migliore M, Barrionuevo G, Ascoli GA: A computer model of unitary responses from associational/commissural and perforant path synapses in hippocampal CA3 pyramidal cells. J Comput Neurosci 2011, 31:137-158

48. Cutsuridis V, Cobb S, Graham BP: Encoding and retrieval in a model of the hippocampal CA1 microcircuit. Hippocampus 2010, 20:423-446.

49. Liu YH, Wang XJ: Spike-frequency adaptation of a generalized leaky integrate-and-fire model neuron J Comput Neurosci 2001, 10:25-45.

50. Lerche H, Jurkat-Rott K, Lehmann-Horn F: Ion channels and epilepsy. Am J Med Genet 2001, 106:146-159.

51. Blalock EM, Chen KC, Vanaman TC, Landfield PW, Slevin JT: Epilepsy-induced decrease of L-type Ca2+ channel activity and coordinate regulation of subunit mRNA in single neurons of rat hippocampal 'zipper' slices. Epilepsy Res 2001, 43:211-226.

52. Zamponi GW, Lory P, Perez-Reyes E: Role of voltage-gated calcium channels in epilepsy. Pflugers Arch 2010, 460:395-403.

53. Wang XJ, Buzsaki G: Gamma oscillation by synaptic inhibition in a hippocampal interneuronal network model. J Neurosci 1996, 16:6402-6413.

54. Wang XJ: Pacemaker neurons for the theta rhythm and their synchronization in the septohippocampal reciprocal loop. J Neurophysiol 2002, 87:889-900.

55. Witter MP: Organization of the entorhinal-hippocampal system: a review of current anatomical data. Hippocampus 1993, 3:33-44.

56. Traub RD, Wong RK, Miles R, Michelson H: A model of a CA3 hippocampal pyramidal neuron incorporating voltage-clamp data on intrinsic conductances. J Neurophysiol 1991, 66:635-650.

57. Jaffe DB, Ross WN, Lisman JE, Lasser-Ross N, Miyakawa H, Johnston D: A model for dendritic Ca2+ accumulation in hippocampal pyramidal neurons based on fluorescence imaging measurements. J Neurophysiol 1994, 71:1065-1077.

doi:10.1186/1742-4682-11-14

Cite this article as: Ren et al:: The role of the entorhinal cortex in epileptiform activities of the hippocampus.

Theoretical Biology and Medical Modelling 2014 11:14.

\section{Submit your next manuscript to BioMed Central and take full advantage of:}

- Convenient online submission

- Thorough peer review

- No space constraints or color figure charges

- Immediate publication on acceptance

- Inclusion in PubMed, CAS, Scopus and Google Scholar

- Research which is freely available for redistribution 